\title{
PEMANFAATAN DATA DIGITAL UNTUK MONITORING AREA TERLUAR KEGIATAN PERTAMBANGAN BLOK 7 BINUNGAN MINE OPERATION 2 - PT. BERAU COAL
}

\author{
Aldi Agus Setiawan ${ }^{1)}$, Iwan Widiadmoko ${ }^{1)}$ dan Hifzil Kirmi ${ }^{1)}$ \\ Environment Departement, PT. Berau Coal Energy \\ Berau - Kalimantan Timur
}

\begin{abstract}
ABSTRAK
PT. Berau Coal melakukan penambangan dengan sistem penambangan terbuka untuk menyesuaikan dengan model geologi batubara area Binungan yang berlapis-lapis (multi seam) dengan kemiringan perlapisan batubara $23^{\circ}-40^{\circ}$. Pada penambangan terbuka (Open Cut Mining) pengelolaan lingkungan disesuaikan dengan metode penambangan gali-sisi kembali (backfilling-method) yang terdapat dalam rencana pengelolaan Lingkungan PT. Berau Coal. Kegiatan penambangan dengan sistem Open Pit sangat bergantung dengan bukaan lahan baru/original untuk dijadikan area disposal (out pit dump). Pada tahun 2019 rencana penimbunan pada area Out Pit sebesar 133,5 juta bcm. Daerah tangkapan air yang berupa area terbuka (disposal), berdampingan dengan area original, hal ini berpotensi terjadinya pencemaran lingkungan akibat air limbah tambang. Pengelolaan dan perlindungan lingkungan hidup merupakan kewajiban bagi perusahaan sebagai bentuk tanggung jawab pelaku usaha dalam pengelolaan lingkungan dalam upaya melestarikan serta mengendalikan pencemaran yang berpotensi merusak lingkungan. Oleh karena itu monitoring area terluar merupakan kegiatan yang sangat penting untuk dilakukan. Untuk mempermudah monitoring, digunakan data digital yang sudah tersedia untuk diolah lebih lanjut agar dapat dianalisa dalam pengambilan keputusan. Pemanfaatan foto udara terbaru yang diambil secara berkala kemudian dilakukan permodelan elevasi digital (Digital Elevation Model) akan di peroleh informasi terbaru mengenai kondisi area terluar kegiatan pertambangan. Kegagalan sistem drainase air limbah tambang yang mengalami perubahan kondisi bangunan dan berpotensi menyebabkan air rilis tanpa melalui titik penaatan akan dapat segera diketahui, sehingga dapat segera dilakukan perbaikan. Pemanfaatan data digital di area Blok 7 Site Binungan Mine Operation 2 memperoleh informasi pengklasifikasian risiko kegagalan akibat perubahan pola aliran air yang kemudian disajikan dalam peta identifikasi risiko aliran air untuk area terluar pertambangan. Peta risiko tersebut menjadi acuan dan menjadi prioritas untuk dilakukan perbaikan dilapangan.
\end{abstract}

Kata Kunci : pengelolaan lingkungan, area terluar, operasional pertambangan, improvement, optimum.

\section{A. PENDAHULUAN}

Konsep pelaksanan pengelolaan lingkungan disesuaikan dengan metode penambangan gali-sisi kembali (backfilling-method) dengan sistem penambangan terbuka (open cut mining) berdasarkan Rencana Pengelolaan Lingkungan PT. Berau Coal yang tertera pada dokumen AMDAL perusahaan. Penerapan sistem penambangan terbuka ini disesuaikan dengan model geologi batubara pada area Binungan Mine Operation yang berlapis-lapis (multi seam) dengan kemiringan perlapisan batubara $23^{\circ}$ - 40 . Operasional pertambangan PT. Berau Coal dengan sistem penambangan Open Cut Mining untuk memperoleh batubara dengan kegiatan spesifik seperti penggalian, pengangkutan dan penimbunan. 
Kegiatan penambangan dengan sistem Open Pit sangat bergantung dengan bukaan lahan original untuk dijadikan area disposal (out pit dump) dengan rencana penimbunan tahun 2019 pada area Out Pit sebesar 133,5 juta bcm. Daerah tangkapan air yang berupa area disposal terbuka, berdampingan dengan area original berpotensi terjadinya penyempitan saluran drainase air limbah tambang. Pengelolaan dan perlindungan lingkungan hidup merupakan kewajiban bagi perusahaan sebagai bentuk tanggung jawab pelaku usaha terhadap pengelolaan lingkungan dalam upaya melestarikan dan mengendalikan pencemaran yang berakibat kerusakan lingkungan.

Pada kegiatan monitoring dan evaluasi, salah satu tahapan penting dalam melakukan monitoring antara lain adalah pengumpulan data. Data yang dikumpulkan dapat bersumber dari penerima manfaat baik perorangan, komunitas ataupun organisasi dan mitra kerja lainnya yang terlibat dalam program yang dijalankan suatu organisasi. Data yang dibutuhkan dari berbagai narasumber berkaitan dengan kualitas pelaksanaan program, pemanfaatan program dan validitas data. Data monitoring yang valid mendukung proses evaluasi dan menghasilkan rekomendasi yang tepat guna.

Digunakannya data penginderaan jauh secara luas untuk melakukan pemantauan kondisi lapangan merupakan salah satu metode pemantauan area operasional kegiatan pertambangan yang sangat dinamis. Dengan kualitas data yang baik dan resolusi data pemetaan yang rinci, dapat mengakomodir kebutuhan perusahaan untuk memastikan pengelolaan lingkungan berjalan dengan baik. Informasi terkait arah operasional pertambangan dapat terekam baik dengan adanya data yang disajikan berupa peta aktual yang diperoleh dengan pemetaan drone serta data digitasi pendukung lainnya.

Analisis data citra yang diperoleh berbasis objek merupakan metode mengekstraksi objek pada citra digital penginderaan jauh yang efisien dan terperinci (Blaschke, 2010: Puissant 2014). Dari observasi data penginderaaan jarak jauh yang dilakukan diperoleh hasil yang menunjukan area-area kritis yang perlu dilakukan tindakan perbaikan. Analisis yang dilakukan dari data observasi penginderaan jarak jauh kurang merepresentasikan kondisi aktual lapangan karena diperlukan informasi detail mengenai permasalahan yang terjadi lapangan (Paski, 2017). Oleh karena itu, perlu dilakukan observasi lapangan guna memperoleh infomasi detail. Perolehan informasi terperinci akan menghasilkan analisis masalah yang akurat sehingga rekomendasi tindakan perbaikan yang dilakukan sesuai dengan permasalahan yang ditemukan di lapangan.

Air limbah dari kegiatan pertambangan batubara adalah air yang berasal dari kegiatan penambangan batubara yang meliputi penggalian, pengangkutan dan penimbunan, baik pada area kegiatan penambangan batubara bawah tanah (tambang dalam) dan penambangan terbuka (Open Pit) (Nugroho et al, 2010). Pengelolaan dan pengolahan air limbah tambang tidak terlepas dari baku mutu air limbah pertambangan yang diatur pada peraturan pemerintah. Ukuran batas atau kadar unsur pencemar dan atau jumlah unsur pencemaran yang ditenggang keberadaannya dalam air limbah batu bara yang akan dibuang atau dilepas ke badan air permukaan merupakan definisi dari baku mutu air limbah batubara. Beberapa parameter yang dipantau pada air limbah kegiatan penambangan batubara diantaranya adalah Total Suspended Solid (TSS), derajat keasaman (pH), total Besi (Fe) dan total Mangan (Mn) (Perda Kaltim No.2 Tahun 2011).

Salah satu program PT. Berau Coal yang dilaksanakan sebagai upaya pemantauan kondisi area terluar dengan pemanfaatan data digital untuk memonitor area terluar guna mengantisipasi potensi yang merugikan lingkungan akibat operasional pertambangan batubara. Terlaksananya program ini atas kolaborasi berbagai departemen, diantaranya adalah:

- Survey and Geospatial Information (SGI) Department,

- Geotechnical and Hydrology $(\mathrm{G \& H})$ Department,

- Environment Department, 
- $\quad$ Short Term Mine Plan Department, dan

- Mining Operation Department.

Kerjasama antar departemen sangat penting untuk mencapai tujuan mencegah dampak yang merugikan lingkungan akibat kegiatan pertambangan. Setiap departemen memiliki peran dan fungsinya masing masing, proses kerjasama serta sinkronisasi yang baik sebagai landasan keberhasilan dalam menjalankan program pemantauan area terluar.

Tabel 1. Peran dan Fungsi Departemen Pendukung

\begin{tabular}{|c|c|c|}
\hline No & Departemen & Peran dan Fungsi \\
\hline 1 & $\begin{array}{l}\text { Survey and Geospatial } \\
\text { Information (SGI) }\end{array}$ & $\begin{array}{l}\text { melakukan pengambilan data elevasi, geometri dan pemetaan. } \\
\text { Data digital tersebut diperlukan untuk penginderaan jarak jauh } \\
\text { dan menghasilkan informasi secara menyeluruh terkait geometri } \\
\text { area pertambangan. }\end{array}$ \\
\hline 2 & $\begin{array}{l}\text { Geotechnical and } \\
\text { Hydrology }\end{array}$ & $\begin{array}{l}\text { melakukan analisa terhadap data digital dan melakukan observasi } \\
\text { permasalahan di lapangan guna memastikan sistem drainase } \\
\text { pertambangan sesuai dengan desain yang berbentuk close circuit. } \\
\text { Sebagai output dari analisa departemen G\&H memberikan } \\
\text { rekomendasi kajian berupa kajian hidrologi. }\end{array}$ \\
\hline 3 & Environment & $\begin{array}{l}\text { melakukan pengukuran kualitas air dan tanah, melakukan } \\
\text { pengukuran besaran potensi terhadap lingkungan, serta } \\
\text { melakukan analisa mengenai potensi dampak lingkungan. }\end{array}$ \\
\hline 4 & Short Term Mine Plan & $\begin{array}{l}\text { membuat perencanaan tindakan perbaikan yang dilakukan secara } \\
\text { menyeluruh dan mengkorelasikan sesuai dengan perkembangan } \\
\text { life of mine (LOM). }\end{array}$ \\
\hline 5 & Mining Operation & $\begin{array}{l}\text { melakukan koordinasi terhadap mitra kerja dan mengawasi } \\
\text { tindakan perbaikan yang dilakukan sesuai dengan rekomendasi } \\
\text { yang ada. }\end{array}$ \\
\hline
\end{tabular}

Dengan tujuan melakukan monitoring area terluar, merencanakan dan melakukan tindakan perbaikan sebagai upaya untuk menjaga pola aliran sesuai dengan sistem close circuit dan memastikan air limbah tambang masuk ke kolam pengelolaan untuk dikeluarkan pada titik penaatan. Program yang terintegrasi dan terpadu atas beberapa departemen ini bertujuan untuk memastikan tidak terdapat potensi pencemaran akibat air limbah tambang yang keluar dari sistem drainase close circuit yang telah direncanakan pada operasional PT Berau Coal.

Pelaksanaan monitoring perubahan kondisi area terluar pertambangan Blok 7 dilakukan dengan data dilakukan secara periodik dan rutin untuk memetakan lokasi dan area yang berpotensi terjadinya perubahan pola aliran air limbah tambang diluar titik penaatan. Dengan pemetaan lokasi dan besaran risiko yang teridentifikasi dari setiap lokasi dapat menjadi acuan rencana perbaikan dan pencegahan sejak dini berupa rencana perbaikan. Selanjutnya implementasi dari rencana perbaikan berdasarkan hasil rekomendasi yang dipastikan berjalan sesuai dengan rekomendasi-rekomendasi dari berbagai departemen.

Konsep Plan, Do, Check, Action (PDCA) tidak terlepas dari continuous improvement yang diterapkan. Secara berkala dilakukan kegiatan evaluasi lapangan untuk memetakan seluruh area sudah terkendali untuk mengurangi dampak risiko yang timbul hingga perencanaan improvement guna memastikan 
operasional tidak berdampak buruk terhadap lingkungan sekitar area pertambangan blok 7 , terutama akibat kegagalan sistem penyaliran air limbah tambang.

\section{B. METODOLOGI PENELITIAN}

\section{B.1. Perolehan Data}

Perolehan data yang dilakukan berdasarkan kaidah-kaidah yang sesuai dengan metode penelitian. Teknik pengumpulan data adalah langkah utama yang paling strategis dalam penelitian, karena tujuan utama dari penelitian adalah mendapatkan data. Pada pelaksanaan program ini dilakukan berbagai teknik pengumpulan data diantaranya teknik wawancara, pengamatan atau observasi, dokumentasi dan triangulasi.

Ragam data yang diperlukan untuk menjalankan program monitoring area terluar terdiri dari data primer. Terdiri dari dua jenis data primer yang diperlukan adalah data primer aktual dan data primer historikal. Data primer aktual adalah data analisa kondisi lapangan yang diperoleh secara aktual dengan waktu pengambilan terkini. Sedangkan data primer historikal adalah data analisa kondisi lapangan di waktu silam yang diambil secara periodik dan termasuk juga data rona awal. Kedua data tersebut digunakan sebagai data pembanding antara rona awal sebelum adanya aktivitas pertambangan dan data aktual setelah adanya kegiatan pertambangan.

Adapun data-data yang diperlukan untuk dilakukan analisa dampak lingkungan adalah sebagai berikut:

- Data digitasi survey dan pemetaan,

- Data dokumentasi lapangan,

- Data kualitas air, dan

- Data catchment area dan hidrologi pertambangan.

\section{B.2. Klasifikasi Jenis dan Sifat Data}

Untuk mempermudah proses pengolahan data, data primer yang diperoleh dari berbagai teknik pengumpulan data kemudian diklasifikasikan menjadi beberapa jenis data. Data hitung berupa angka atau bilangan numerik berbentuk nilai dan persentase dari suatu jumlah pada data tertentu. Pada data hitung biasanya berupa hasil pengukuran koordinat, jarak, kemiringan lereng, laju alir dan kualitas air limbah tambang. Sedangkan data yang menunjukkan ukuran mengenai nilai sesuatu disebut data ukur berasal dari penilaian sifat permasalahan yang kemudian data ini dilakukan penilaian terhadap potensi dampak terhadap lingkungan.

\section{B.3. Pengolahan Data}

Pengolahan data merupakan proses manipulasi data agar menjadi bentuk lain yang lebih berguna dan mampu memberikan informasi. Pengolahan data tidak hanya berupa perhitungan bilangan numerik tetapi juga operasi-operasi seperti pengklasifikasian data maupun pemindahan data dari tempat ke tempat lainya. Operasi-operasi tersebut dilaksanakan oleh mesin pengolah data atau perangkat komputer maupun beberapa diantaranya dilakukan secara manual.

Pembuatan peta kategori risiko dilakukan pembaruan pada setiap bulannya menggunakan metode analisa citra dengan basis objek. Data digital citra drone terbaru menjadi referensi untuk menghasilkan peta membentuk pola aliran dan pengkategorian status risiko. Proses pengolahan data secara manual dilakukan untuk memperbaiki klasifikasi secara visual dengan menggunakan referensi citra beresolusi tinggi dari citra pengambilan gambar dengan perangkat drone. 


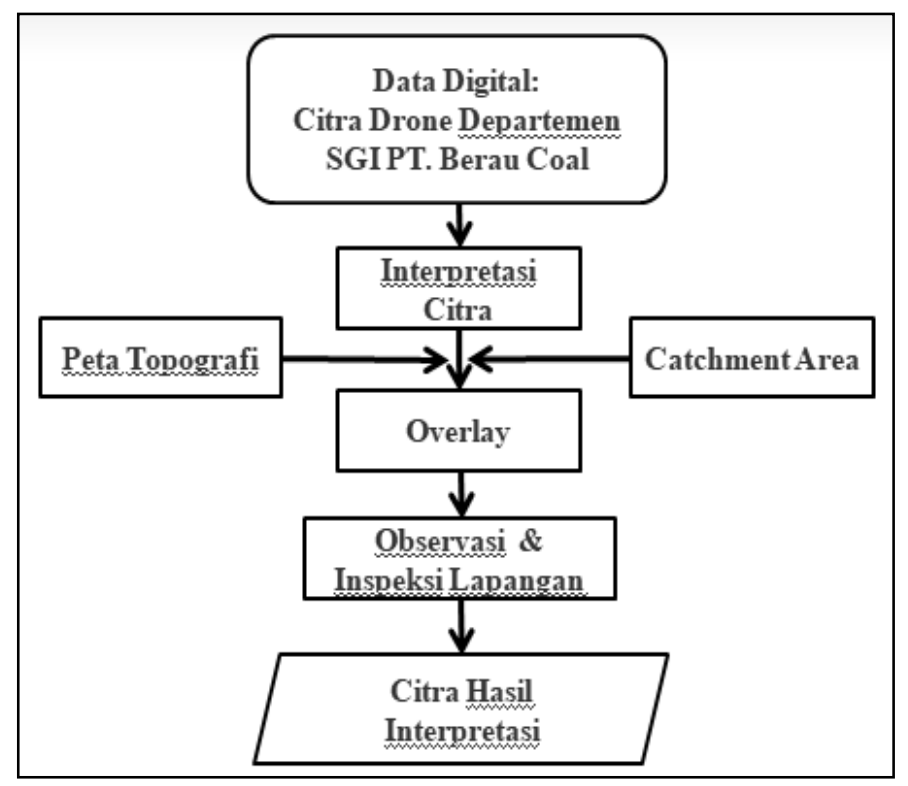

Gambar 1. Diagram Alir Pengolahan Data Citra

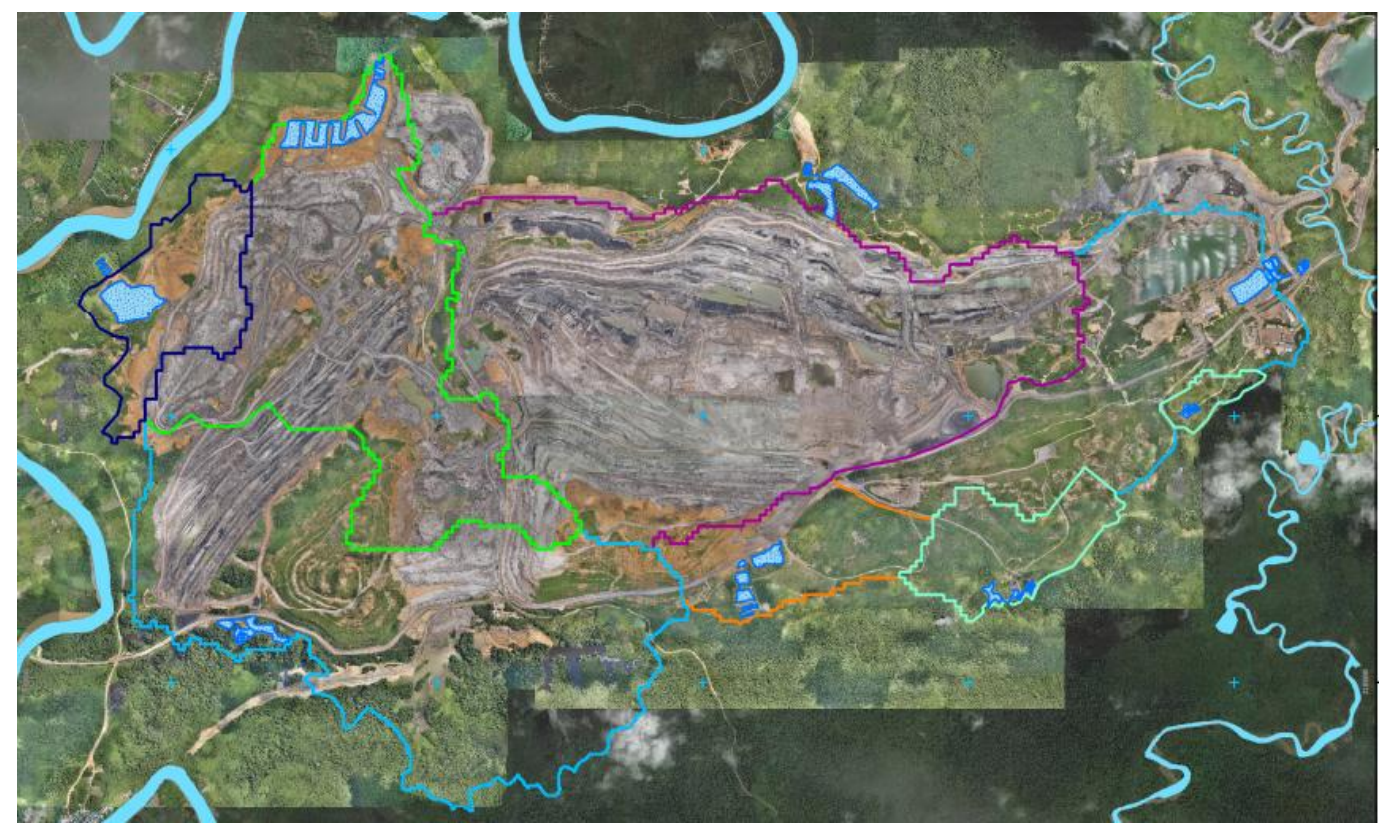

Gambar 2. Peta Citra Drone SGI Operasional Pertambangan Blok 7, Binungan Mine Operation 2

Selain data digital pemetaan menggunakan drone, diperlukan data digitasi topografi, catchment area dan drainase area pertambangan Blok 7 sebagai data pembanding antara perencanaan dan kondisi aktual lapangan. Berikut ini adalah data digitasi menggunakan software hidrologi dan melakukan koreksi secara manual menyesuaikan dengan data kondisi aktual di lapangan. 


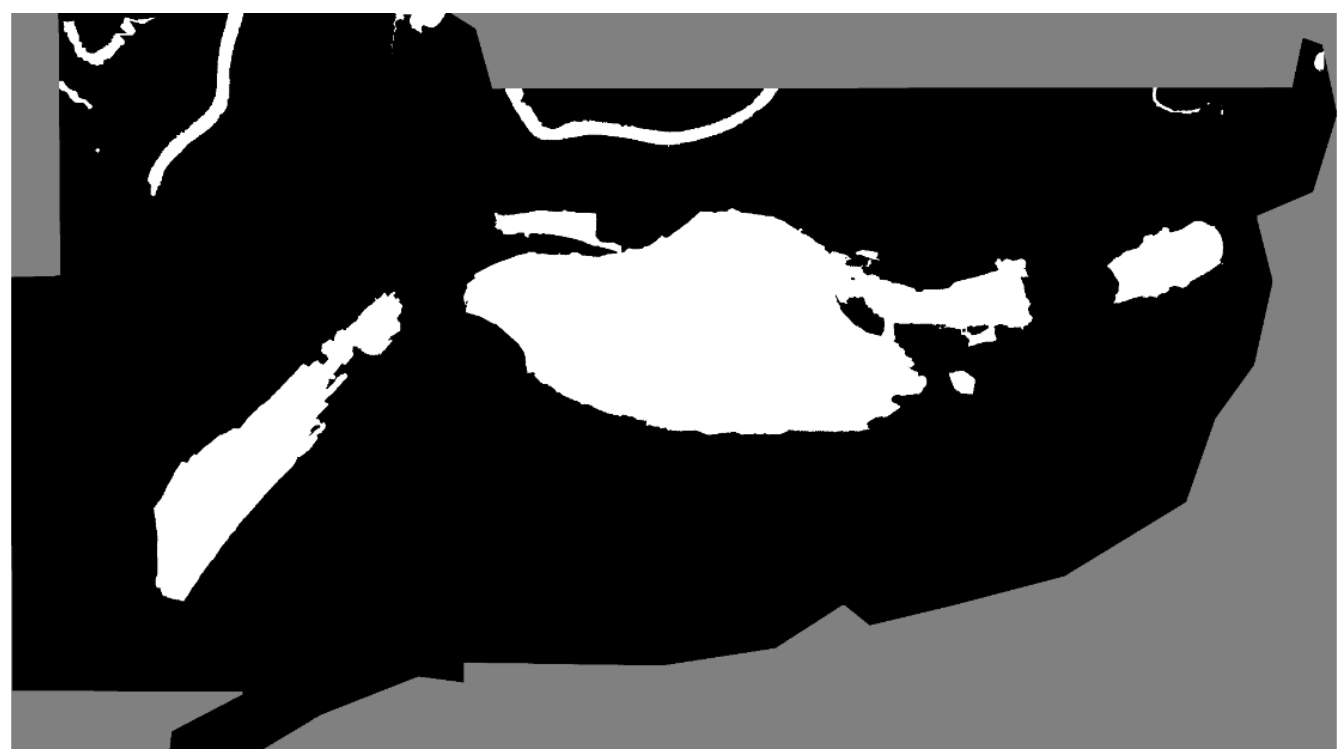

Gambar 3. Peta Digital Elevation Model Area Pertambangan Blok 7, Binungan Mine Operation 2

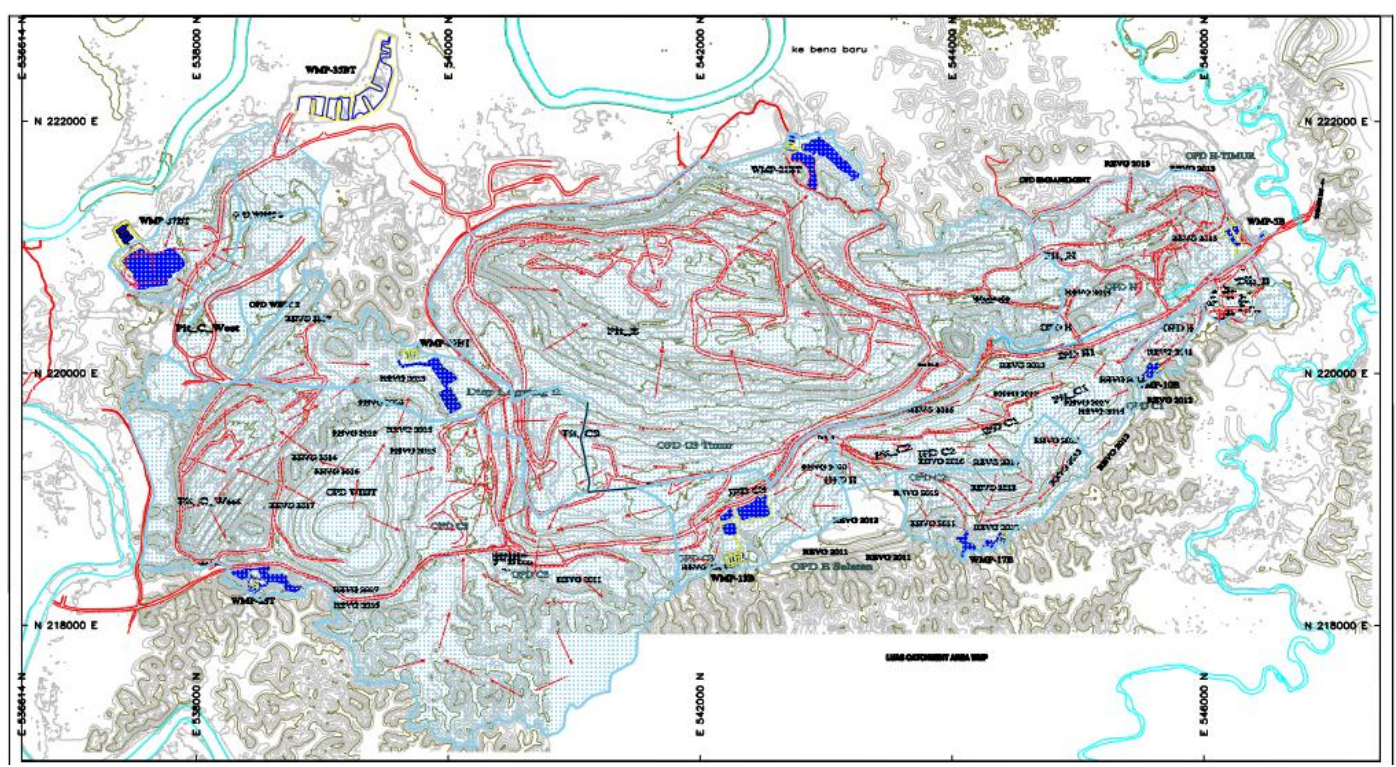

Gambar 4. Peta Catchment Area dan Drainase Pertambangan Blok 7, Binungan Mine Operation 2

\section{HASIL DAN PEMBAHASAN}

\section{C.1. Pemetaan Risiko Lingkungan}

Data digital citra intepretasi yang didukung data topografi dan catchment area menghasilkan data overlay pemetaan titik kritis yang tersebar di beberapa lokasi area operasional pertambangan. Penentuan titik kritis pada beberapa lokasi himpunan dari data historikal yang sebelumnya merupakan area disposal, area genangan air, area-area yang pernah berpotensi kegagalan drainase yang telah dilakukan pengendalian dini, ataupun area kritis lainnya yang berpotensi memberikan dampak lingkungan. Selain data historikal, data aktual dihimpun dari kegiatan inspeksi rutin yang dilakukan setiap minggunya. Data aktual yang terkumpul memperbaharui status risiko kondisi area kritis pada masing-masing titik yang sudah diplot pada data overlay. 


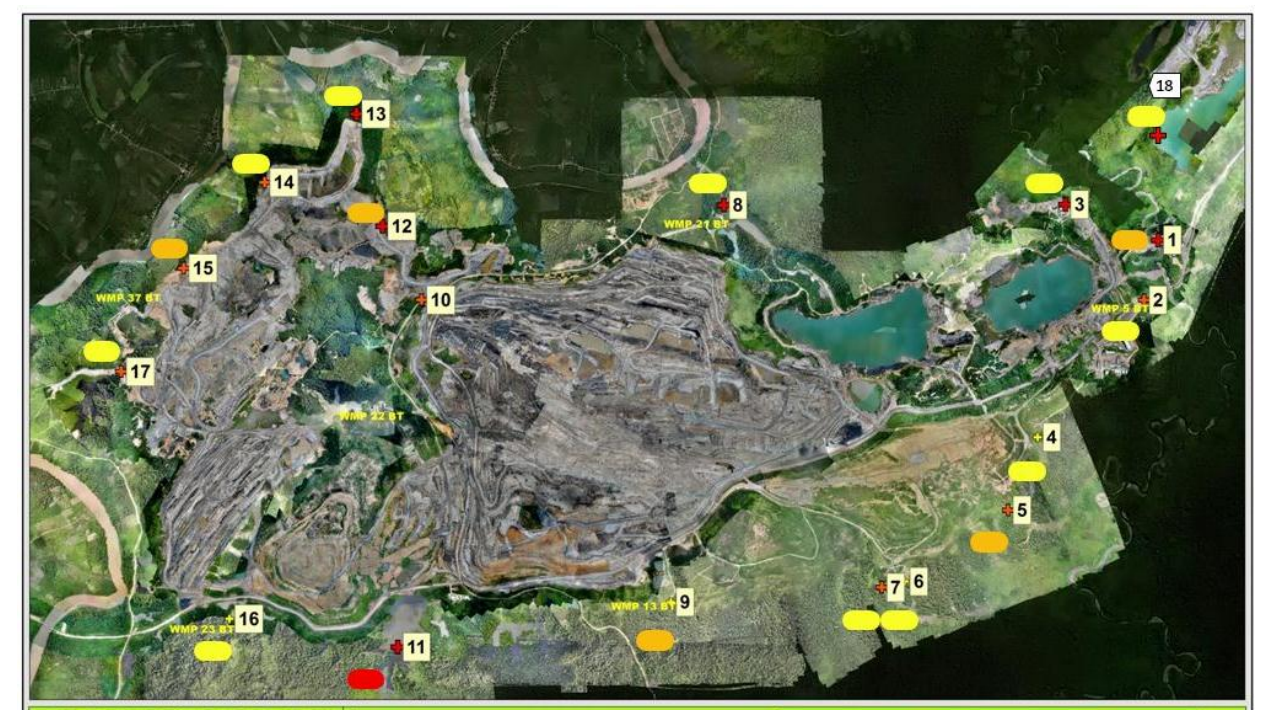

Gambar 5. Peta Area Titik Kritis Area Terluar Pertambangan Blok 7, Binungan Mine Operation 2

Analisis data menghasilkan pemetaan sebanyak 18 titik area kritis terluar yang perlu dilakukan pemantauan secara periodik dan rutin. Masing-masing titik memiliki status risiko yang berbeda-beda, menyesuaikan dengan kondisi aktual. Gradasi warna pada masing-masing titik menunjukkan status risiko pada masing-masing titik. Pembagian status risiko "Ringan" berwarna kuning menunjukkan area tersebut masih dalam status siaga namun tetap dilakukan pengawasan minimal 1 kali perminggu, pada status risiko "Sedang" menunjukkan kondisi awas dan berpotensi menjadi tinggi ketika terjadi perubahan cuaca seperti curah hujan tinggi lebih dari 3 jam dan dilakukan pengawasan minimal 2 kali per minggu. Sedangkan pada titik dengan status risiko "Tinggi" menunjukkan kondisi yang sewaktuwaktu dapat berubah ketika terjadi perubahan cuaca dan perlu dilakukan inspeksi secara rutin setidaknya setiap hari mengikuti perkembangan cuaca.

\section{C.2. Pengendalian Risiko}

Pengkategorian status risiko pada setiap titik merupakan pedoman untuk melakukan inspeksi secara rutin. Semakin tinggi status risiko pada sebuah titik, maka pengawasan lokasi tersebut semakin ketat atau semakin sering lokasi tersebut di observasi. Adapun pembagian tindakan mitigasi sesuai masingmasing kategori risiko disajikan pada Gambar 6.

Seiring dengan tindakan perbaikan yang dilakukan oleh pada masing-masing area kritis kemudian dapat mengubah status risiko. Kegiatan perbaikan yang dilakukan kemudian dilakukan penilaian (assessment) terhadap kesesuaian dengan tindakan perbaikan yang telah direkomendasikan oleh masing-masing departemen yang terkait.

\section{C.3. Evaluasi terhadap Implementasi Program}

Implementasi program monitoring area terluar merupakan suatu wujud komitmen perusahaan dalam menjalankan kaidah pertambangan yang ramah lingkungan. Penerapan program ini merupakan suatu bentuk improvement perusahaan dalam menjalankan kewajiban pemantauan dan pengelolaan lingkungan untuk menjaga operasional pertambangan memenuhi aturan yang berlaku. Konsistensi terhadap pelaksanaan program akan mencegah kegagalan sistem drainase penyaliran tambang dan mengurangi gangguan terhadap proses operasional dan pencemaran lingkungan. Berikut adalah grafik perubahan kondisi lapangan selama implementasi program yang telah berjalan selama kurang lebih 13 bulan. 


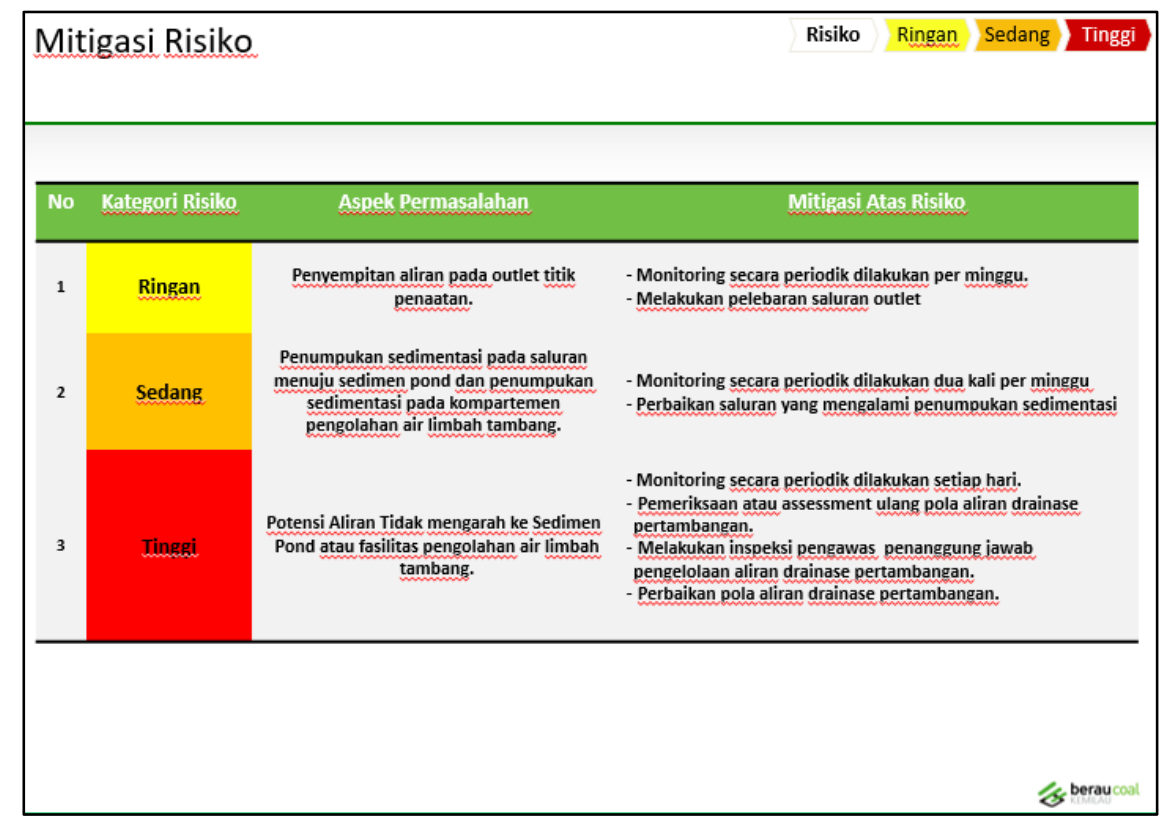

Gambar 6. Matriks Mitigasi Risiko pada Setiap Kategori

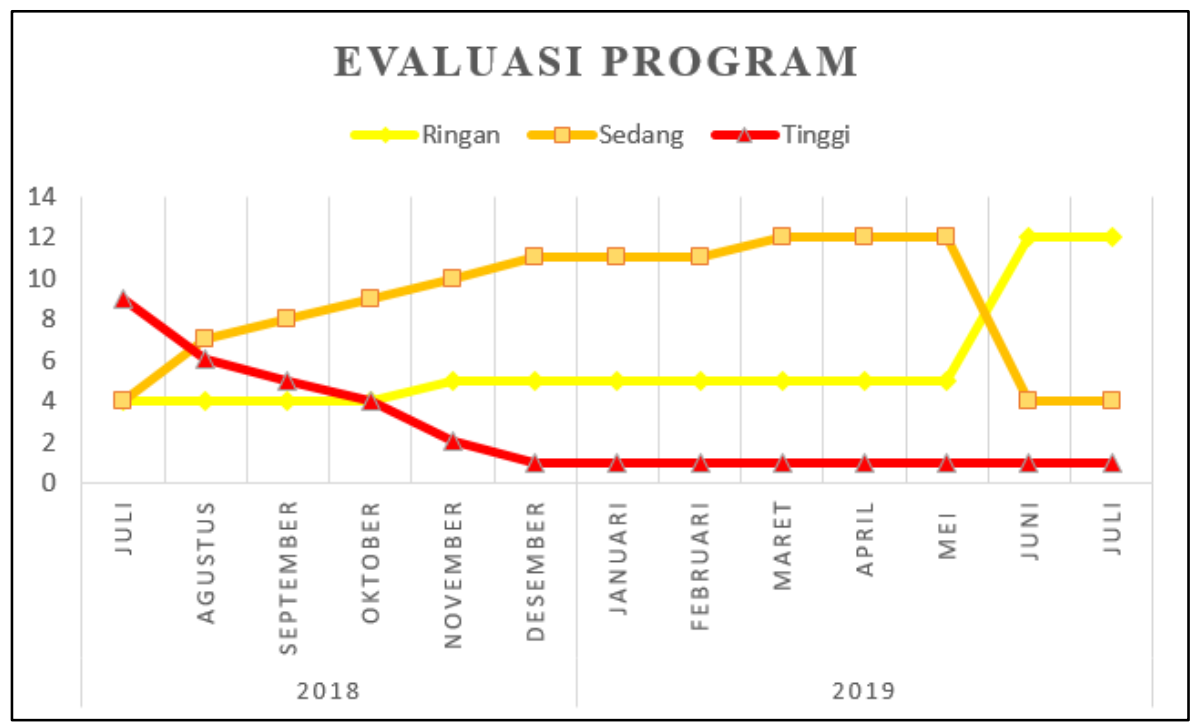

Gambar 7. Grafik Evaluasi terhadap Implementasi Program

Berdasarkan grafik yang ditampilkan, terdapat data evaluasi terhadap implementasi program dengan berbagai perubahan jumlah pada status risiko sesuai dengan kondisi aktual di lapangan. Terdapat tiga status risko dengan kategori "Ringan", "Sedang" dan "Tinggi" dengan implementasi program selama 13 bulan yang dimulai sejak bulan Juli tahun 2018. Pada grafik status risiko "Tinggi", deviasi awal kondisi lapangan dengan jumlah 9 titik lokasi, dengan implementasi program mengalami penurunan jumlah status risiko setiap bulannya hingga tersisa 1 titik lokasi yang terjadi di bulan Desember tahun 2018 hingga bulan Juli tahun 2019. Pada grafik status risiko "Sedang", terdapat peningkatan status risiko dengan deviasi awal berjumlah 4 titik lokasi kemudian mengalami peningkatan hingga jumlah maksimal 12 titik. Penambahan status risiko "Sedang" berasal dari titik yang sebelumnya dengan status risiko "Tinggi" yang berjumlah 8 titik lokasi. Hingga pada bulan Mei tahun 2019, titik dengan status risiko "Sedang" dilakukan tindakan perbaikan sampai mengalami penurunan dengan jumlah 4 titik 
lokasi pemantauan dan perbaikan. Sedangkan pada grafik status risiko "Ringan", terdapat peningkatan grafik dari awal implementasi bulan Juli tahun 2018 dengan jumlah 4 titik lokasi sampai dengan bulan Juli tahun 2019 dengan jumlah 12 titik lokasi. Dengan adanya tindakan perbaikan yang dilakukan, kenaikan jumlah status risiko "Ringan", berbanding lurus dengan penurunan jumlah status risiko "Sedang".

Berdasarkan penelitian sekaligus implementasi program pelaksanaan pemantauan lingkungan ini, dengan penggunaan data digital memberikan hasil yang baik dalam efisiensi pekerjaan monitoring dan evaluasi. Kualitas gambar pemetaan dengan pesawat tanpa awak (drone) berupa kondisi aktual sangat diperlukan, dengan pengambilan kualitas gambar yang baik maka diperoleh hasil pengamatan dengan nilai akurasi yang tinggi. Selain itu, nilai akurasi yang tinggi dari data topografi yang diperoleh mempengaruhi hasil analisa pemetaan area kritis area operasional pertambangan Blok 7, Site Binungan Mine Operation 2.

Dari penelitian ini diperoleh hasil pemetaan area kritis dengan jumlah 18 titik dengan pemetaan status risiko pada masing-masing titik kritis. Persebaran area kritis pada area operasional Pertambangan Blok 7 dengan kategori "Ringan" dengan persentase sebesar 72.2\% (13 titik kritis), kategori "Sedang" dengan persentase sebesar 22\% (4 titik kritis), dan kategori "Tinggi" dengan persentase sebesar 0.05\% (1 titik kritis). Dengan implementasi program pemantauan area terluar dengan penurunan status risiko "Tinggi" sebesar $72 \%$, dan kenaikan status risiko "Ringan" persentase $200 \%$ dari awal berjalannya program. Dengan berjalanya program ini dinilai mampu menjalankan fungsi pemantauan dan pengelolaan lingkungan serta mampu mencegah potensi pencemaran lingkungan area Pertambangan Blok 7, Binungan Mine Operation 2.

Penilaian status risiko didukung oleh pengambilan data aktual lapangan secara perodik sehingga informasi yang diperoleh dengan akurasi tinggi. Pemetaan area kritis dapat mempermudah untuk pemantauan kondisi terbaru dengan pembagian status risiko pada setiap titik, mempermudah pengawas operasional dalam melakukan monitoring dan memastikan area operasional pertambangan tidak memberikan dampak yang buruk bagi lingkungan sekitar akibat pencemaran air limbah tambang.

\section{UCAPAN TERIMA KASIH}

Penulis dalam hal ini mengucapkan terima kasih yang dituju kepada pihak yang telah membantu pihak baik penyedian data, pengerjaan data, kepada PT. Berau Coal, serta rekan kerja khususnya departemen Mining Operation, Survey and Geospatial Information, Geotech and Hidrology, Short Term Mine Plan dan Environment area kerja Binungan Mine Operation 2 yang telah membantu penulis baik penyediaan data, pengerjaan data sehingga penulis dapat menyelesaikan penelitian ini.

\section{DAFTAR PUSTAKA}

Indrawati, Like dan Cahyono,A, (2018):Pemanfaatan Data Landsat Multitemporal Untuk Pemetaan Pola Ekspansi Perkotaan Secara Spasiotemporal (Studi Kasus Pada Tiga Perkotaan Metropolitan di Pulau Jawa), Jurnal Nasional Teknologi Terapan, Vol. 2 No.1.

Lei Ma, Tenyu Fu, Thomas Blaschke, Marchun Li, Dirk Tiede, Zhenjin Zhou, Xiaoxue Ma, dan Deliang Chen, (2017), Evaluation Of Feature Selection Methods for Object-Based Land Cover Mapping of Unnamed Aerial Vehicle Imagenary, ISPRS, Int. J. Geo-Inf., 6:51;doi:10.3390/ijgi6020051 www.mdpi.com /journal/ijg. Diunduh pada tanggal 21 Juli 2019.

Nugeraha, Sri Sumiyati, dan Ganjar Samudro (2010), Pengolahan Air Limbah Kegiatan 
Penambangan Batubara Menggunakan Biokoagilan : Studi Penurunan Kadar TSS, Total Fe dan Total Mn Menggunakan Biji Kelor (Moringa oleifera), Jurnal PRESIPITASI Vol. 7 No. 2 September 2010, ISSN 1907-187X.

Paski, Jaka Anugrah Ivanda, (2017), Pengaruh Asimilasi Data Penginderaan Jauh (Radar dan Satelit) Pada Prediksi Cuaca Numerik Untuk Estimasi Curah Hujan (Impact of Remote Sensing Data Assimilation(Radar and Satelite) On Numerical Weather Prediction for Rainfall Estimation), Jurnal Penginderaan Jauh Vol. 14 No. 2 Desember 2017 : 79-88.

Pemerintah Negara Republik Indonesia, (2009), Undang-undang Nomor 32 Tahun 2009 Tentang Perlindungan dan Pengelolaan Lingkungan Hidup, Jakarta.

Pemerintah Provinsi Kaltim, (2011), Peraturan Daerah Kalimantan Timur Nomor 2 Tahun 2011 Tentang Pengelolaan Air dan Pengendalian Pencemaran Air, Samarinda.

Sugiyono, (2009), Metode Penelitian Kuantiatif, Kualitatif dan R\&D (Edisi Cetakan ke -9, Oktober 2013), Penerbit Alfabeta, CV. Bandung.

Syahid, Bilal, Data - Pengertian, Fungsi, Jenis, Sifat, Sumber, Pengumpulan, Pengukuran, Sumber, Para Ahli, https://www.gurupendidikan.co.id/data/. Diunduh pada tanggal19 Juli 2019. 